\title{
POSSIBLE SIGHTING OF ESKIMO CURLEWS (Numenius borealis)
}

BOB WALDON, Box 338, Alert Bay, BC. VON 1 A0

On 15 May 1996, Gwen and Lloyd Powell of Killarney, Manitoba, were out checking one of Lloyd's bluebird house lines south of town, tending to a hobby of some twenty years' standing. That spring having been a late and wet one, the sloughs were brimming and there were lots of meltwater ponds still sitting in pastures and fields.

At the time of the sighting they were at the south-east corner of SE8-2-17, two miles west of Highway \#18, on Fletcher Road, five miles south of Killarney. It was a clear, calm day; the temperature was "comfortable."

Around 10:00 a.m. they got out of their car and were walking down a little-used road when Lloyd spotted three shorebirds at the edge of a meltwater pond just to the west of the road allowance. He said, "I have been observing birds for over sixty years. They caught my attention immediately because they were so different."

With mounting excitement the Powells slowly approached to within 25 or $30 \mathrm{~m}$ of the birds. The birds remained indifferent to their presence and went on with their busy feeding, allowing the Powells approximately half an hour to observe them under excellent viewing conditions, and for Lloyd to take notes. They both had binoculars, an $8 \times 40$ Bushnell and an $8 \times 21$ Tasco. The field guide they had was Peterson's Eastern Birds, 1980 edition.
When they returned home Lloyd immediately transcribed his notes into the following report (metrics added subsequently):

"All birds were similar in colour. In comparison to a Killdeer which was near and beside them these birds were larger, 11 to 14 inches (28-35.5 $\mathrm{cm}$ ) in length, about 3.5-4.0 inches $(9-10 \mathrm{~cm})$ in body height. (Body height in this case is an estimate of the distance from the bottom of the breast to the crown of the head.) (The) Bill was about 2 inches $(5 \mathrm{~cm}$ ) long with a slight down curve at the end. The birds appeared to be about $10-12$ inches $(25-30.5 \mathrm{~cm})$ in total height.

"The birds were mottled orangey brown, darker on back than front. Wing tips and tail were dark brown or black. Legs looked darker, maybe a dark grey. The head and beak were dainty, with light stripes and brown stripes on the head, light stripe over the eye.

"The birds were feeding in a shallow pond in a stubble field. They fed in the water, wading around, and seemed to pick insects off the water. They did not put their heads under water. They also picked up items from the shore at the water's edge and maybe a foot or two from the edge. They did not swim that we saw, but waded in shallow water at the edge of the pond. There were frogs croaking near us, but Gwen could hear a sound like 'dee, dee, dee.' 
"These were birds that I have never seen before - I am familiar with Marbled Godwits, Willets, Whimbrels, and Yellowlegs. The description seemed to fit very well (with the illustration of the Eskimo Curlew in our field guide)."

Regrettably, the Powells had neither a film camera nor a video camera to record these birds.

The bird most closely resembling the Eskimo Curlew is the Little Curlew, Numenius minutus, a Siberian breeder recorded, as of 1993, only twice in North America. Both of these were autumn sightings in California, in 1984 and 1988 (Paulson, Shorebirds of the Pacific Northwest, 1993, p. 185).

The major field guides list the Eskimo Curlew as "nearly extinct," a classification that many in the birding community regard as optimistic. In the Atlas of Saskatchewan Birds, by Alan R. Smith, 1996, the Eskimo Curlew is categorized, sadly, as "hypothetical." According to Smith, the only recent record in Saskatchewan occurred near Regina on 14 May 1982.

The assumption that this onceabundant shorebird has gone the way of the Passenger Pigeon was firmly established in the public mind by the publication in 1955 of Fred Bodsworth's best-selling The Last of the Curlews, a poignant imaginary account of the life of the last surviving bird of its species.

Historically, Eskimo Curlews, which bred, or more hopefully, breed, in the high Arctic, followed a migration pattern similar to that of the Lesser Golden Plover - south down the east coast to their wintering grounds in southern South America, north through the prairie states and provinces. It was during their fall migration, past the market and pot hunters of the eastern seaboard, that they were gunned to virtual oblivion in the 1880s. These were the birds referred to in the game trade as "dough-birds" because of the layer of white fat encasing their bodies.

The only encouraging element in this sorry chronicle of human greed and indifference is the ongoing record of fortuitous sightings from widely scattered locations. One must hope they are valid, and if so that these remnant survivors may eventually be able to restore the multitudes that were devastated so brutally.

(Editor's note: See Volume 52 No. 2 page 104 for another account about this endangered species)

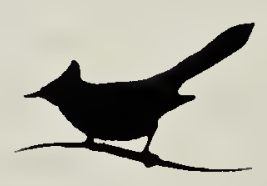

With the help of other systematists, I recently estimated the number of known species of organisms, including all plants, animals, and microorganisms, to be 1.4 million. This figure could easily be off by a hundred thousand, so poorly defined are species in some groups of organisms and so chaotically organized is the literature on diversity in general. More to the point, evolutionary biologists are generally agreed that this estimate is less than a tenth of the number that actually live on earth. E.O. Wilson, 1992. The diversity of life. W.W. Norton and Company, New York. 424 pp. 